\title{
SOCIO-DEMOGRAPHIC CHARACTERISTICS OF MALE CONTRACEPTIVE USE IN INDONESIA
}

\author{
Dian Kristiani Irawaty ${ }^{1,2}$ and Hadi Pratomo ${ }^{2, *}$ \\ ${ }^{1}$ The Indonesia Population and Family Planning Board, Jakarta-13610, Indonesia. \\ ${ }^{2}$ Faculty of Public Health, Universitas Indonesia, Depok-16424, Indonesia. \\ *Corresponding author: Hadi Pratomo \\ Email: pratomohadi@gmail.com
}

\begin{abstract}
Low contraceptive uptake among men remains significant issues in Indonesia. Hence, this study seeks to understand the association between socio-demographic factors and men's contraceptive use in Indonesia by utilizing the 2012 Indonesia Demographic and Health Survey (IDHS), couple dataset. Bivariate analysis was conducted by performing a chi-squared test of independence to analyse the relationship between selected socio-demographic factors and the dependent variable. A binary logistic regression model was considered to identify the effects of covariates. Place of residence, husbands' approval on family planning, husbands and wives knew family planning from newspaper/magazine, and the perception that contraception is woman's business were significant predictors according to the IDHS. Programs related to gendersensitive campaign about family planning and gender-sensitive curricula in schools are needed for encouraging men to use contraception.
\end{abstract}

Keywords: Indonesia Demographic and Health Survey, couple dataset, male contraception

\section{INTRODUCTION}

The involvement of men in reproductive health matters is crucial to achieve Sustainable Development Goals (SDGs). Goal number 5.6 of the SDGs has targeted for ensuring universal access to sexual and reproductive health and reproductive rights ${ }^{1}$. Moreover, the global commitment, which linked to the Program of Action of the International Conference on Population and Development (ICPD) and the Beijing Platform for Action, has been declared to include men in family planning and reproductive health programs $\mathrm{s}^{2,3}$.

Although the Indonesia Government has ratified those global commitments, it's National Development Policy has more focus on women. The 2010-2015 Indonesia National Development Plan had formally targeted male contraceptive prevalence rate to reach $5 \%$ in $2015^{4}$. Unlike the previous one, the 2015-2019 Indonesia National Development Plan's target has not clearly considered men to be the main part of the Family Planning program ${ }^{5}$. This condition has reinforced the believe that family planning is largely a woman's business while the man has a very peripheral role ${ }^{6,7}$. Thus, most of the contraceptive services, research, and campaigns particularly for men tend to be lack behind ${ }^{8,9}$.

The trend has also revealed that female has a higher prevalence than male to use a contraceptive. Only one man compares to twelve women in Indonesia use contraception ${ }^{10}$. The prevalence rate for modern female methods had increased from $55.7 \%$ in 2007 to $55.9 \%$ in $2012^{10,11}$. Nevertheless, the prevalence rate for male sterilization had steady in $0.2 \%$ from 2007 to $2012^{10,11}$. Condom prevalence rate had increased slowly from $1.3 \%$ in 2007 to $1.8 \%$ in $2012^{10,11}$. The rate for periodic abstinence decreased from 1.5\% in 2007 to $1.2 \%$ in 2012 while withdrawal has also dropped from $2.1 \%$ in 2007 to $1.3 \%$ in $2012^{10,11}$.

Determinants of male contraceptive use are varied and complex. Some researchers argued that the place of residence may influence the availability of male contraception as well as its services since most of the health providers tend to stay in urban areas ${ }^{12-15}$. The others suggest male contraceptive use depends on the husband's approval on family planning ${ }^{14,16}$ and positive perception regarding contraception towards family planning ${ }^{17-21}$. Furthermore, the exposure of couples on family planning issues through newspaper/magazine is associated with the increasing knowledge of contraception in Bangladesh and Indonesia ${ }^{22,23}$.

Therefore, this study attempts to examine associated socio-demographic factors contributed to male contraceptive use based on the 2012 Indonesia Demographic and Health Survey (DHS) data. The findings of the study are expected to contribute to further intervention needed. 


\section{METHODS}

Data are drawn from the couple data set based on the 2012 Indonesia Demographic and Health Survey $(\text { IDHS })^{10}$. The couple dataset was linked between 8.246 women aged 10-49 years' female samples and men aged 15-59 years who have married or living together for five years preceding the survey ${ }^{10}$. Weighted analysis was used to account for the complex survey design ${ }^{24}$.

The independent variables of this study were place of residence, age of wife and husband, marital duration, number of living children, husband's approval on family planning, husbands and wives knew family planning from newspaper/magazine, and perception that contraception is woman business. The dependent variable was the current use of contraceptive reported by male's respondents. The current method use was classified into two categories: (0) currently not using any male method and (1) currently using any male methods. Male methods used in the study refer to a contraceptive method that men can use directly or need male cooperation to use such as condom, male sterilization, withdrawal, and periodic abstinence ${ }^{25}$.

The Statistical Package for Social Science (SPSS) version 23 was used to analyse the data ${ }^{26}$. Univariate analysis was used to analyse the frequency distribution of the respondent ${ }^{27}$. In multivariate analysis, the logistic regression was applied in measuring the effect of several significant independent variables towards male contraception $\mathrm{use}^{28}$. Multicollinearity issue will also be considered in the modelling process ${ }^{28}$. Only the final model will be discussed in the study.

Ethical clearance of this study was obtained from the Faculty of Public Health, Universitas Indonesia on September $17^{\text {th }}, 2018$. Informed consent was obtained from all participants. All identifications in the questionnaires were excluded from the study to ensure confidentiality and privacy.

\section{RESULTS}

Table 1 revealed the socio-demographic characteristics of the respondents. The result of the univariate analysis showed that the proportion of the couple lived in the urban area was similar to those living in the rural area $(46.9 \%$ in urban and $53.0 \%$ in rural). Young married women (less than 20) represented only 2.9 of the respondents' whereas $48.6 \%$ of female respondents aged $20-34$ and $50.1 \%$ of the female respondents aged more than 35 years old. Most (51.5\%) of the male respondents aged $25-39$ years old; $43.7 \%$ of them aged more than 40 years old and only $4.6 \%$ of the male respondents aged less than 25 years old. Regarding marital status, the majority $(61.6 \%)$ of the couples were married for more than 15 years while $18.6 \%$ of them were married for $5-14$ years and $19.8 \%$ of them were married for less than 5 years. Nearly $55.9 \%$ of the respondents had 1-2 children while $28.2 \%$ of the respondents had $3-4$ children, $7.7 \%$ of the respondents had more than 5 children and only 0.8 of the respondents had no children. Only $6.4 \%$ of the respondents rely on male methods while $93.6 \%$ of the respondents using other methods.

Table 1. Socio-demographic characteristics of couples in Indonesia, $2012(n=8,225)$

\begin{tabular}{|c|c|c|}
\hline Characteristics & $\mathbf{N}$ & $\%$ \\
\hline \multicolumn{3}{|c|}{ Place of residence } \\
\hline Rural & 4,361 & 53.0 \\
\hline Urban & 3,864 & 46.9 \\
\hline \multicolumn{3}{|l|}{ Age of wife } \\
\hline Less than 20 & 242 & 2.9 \\
\hline $20-34$ & 4,122 & 48.6 \\
\hline 35 and above & 3,861 & 50.1 \\
\hline \multicolumn{3}{|l|}{ Age of husband } \\
\hline Less than 25 & 339 & 4.6 \\
\hline $25-39$ & 4,233 & 51.5 \\
\hline 40 and above & 3,593 & 43.7 \\
\hline \multicolumn{3}{|c|}{ Marital duration (years) } \\
\hline Less than 5 & 1,633 & 19.8 \\
\hline $5-14$ & 1,527 & 18.6 \\
\hline 15 and above & 5,065 & 61.6 \\
\hline \multicolumn{3}{|c|}{ Number of living children } \\
\hline 0 & 665 & 0.8 \\
\hline $1-2$ & 4,605 & 55.9 \\
\hline $3-4$ & 2,320 & 28.2 \\
\hline 5 and above & 635 & 7.7 \\
\hline \multicolumn{3}{|c|}{ Currently, use male contraceptives } \\
\hline Not using & 7,702 & 93.6 \\
\hline $\begin{array}{l}\text { Currently } \\
\text { using }\end{array}$ & 523 & 6.4 \\
\hline
\end{tabular}

Table 2 revealed the results of bivariate and logistic regression analysis. Place of residence, husband's approval on family planning, husbands' know family planning from newspaper/ magazine, wives know family planning from newspaper/ magazine and perception that contraception is woman business were found to be associated with male contraceptive use in Indonesia. Among those variables, approval from the husband had a significant correlation towards male contraceptives than other variables $[2.1(95 \% \mathrm{Cl}, 1.1-4.1)]$.

In 2012, the urban couple was more likely to use male contraception than their rural counterparts [0.6 $(95 \% \mathrm{Cl}, 0.5-0.7)]$. For husbands who approve family planning had greater odds to use male contraception than husbands who disapprove 
family planning $[2.1(95 \% \mathrm{Cl}, 1.1-4.1)]$. Among various sources of information, the results showed that couples whose husbands $[1.6(95 \% \mathrm{Cl}, 1.3$ 1.9)] and wives [1.7 (95\% Cl, 1.4-2.2)] knew family planning from newspaper/magazine had greater probabilities to use male contraception than the non-exposures. For perception, couples whose husbands disagree that contraception is woman business had more likely to use male contraceptives [0.5 $(95 \% \mathrm{Cl}, 0.4-0.6)]$ compared to those who agree with the perception. The result of multicollinearity test revealed that no interassociations among the independent variables.

Table 2. Bivariate and Logistic Regression Predicting Male Contraception Use in Indonesia, $2012(\mathrm{n}=8,225)$

\begin{tabular}{|c|c|c|c|c|c|c|}
\hline \multirow[t]{2}{*}{ Variables } & \multirow[t]{2}{*}{ Category } & \multicolumn{2}{|l|}{ Male contraception } & \multirow[t]{2}{*}{ OR } & \multirow[t]{2}{*}{$95 \% \mathrm{Cl}$} & \multirow[t]{2}{*}{ p-value } \\
\hline & & Not using & Currently using & & & \\
\hline \multirow[t]{2}{*}{ Place of residence } & Rural & $4,183(95.9 \%)$ & $178(4.1 \%)$ & & & \\
\hline & Urban & 3,519 (91.1\%) & 345 (8.9\%) & 0.6 & $0.5-0.7$ & 0.01 \\
\hline \multirow{3}{*}{$\begin{array}{l}\text { Husband's approval } \\
\text { on family planning }\end{array}$} & Disapprove & $52(81.3 \%)$ & 497 (9.8\%) & & & \\
\hline & Approves & 4593 (90.2\%) & $12(18.8 \%)$ & 2.1 & $1.1-4.1$ & 0.02 \\
\hline & Don't know & 3057 (99.5\%) & $14(0.5 \%)$ & 0.04 & $0.2-0.6$ & 0.07 \\
\hline Husbands knew FP & No & 6,367 (94.6\%) & 363 (5.4\%) & & & \\
\hline $\begin{array}{l}\text { from newspaper/ } \\
\text { magazine }\end{array}$ & Yes & 1,335 (89.3\%) & $160(10.7 \%)$ & 1.6 & $1.3-1.9$ & 0.01 \\
\hline Wives knew FP & No & 6,638 (94.5\%) & $386 \quad(5.5 \%)$ & & & \\
\hline $\begin{array}{l}\text { from newspaper/ } \\
\text { magazine }\end{array}$ & Yes & $1,064(87.8 \%)$ & $137(11.4 \%)$ & 1.7 & $1.4-2.2$ & 0.01 \\
\hline Perception: & Agree & 3083 (91.5\%) & 127 (4.0\%) & & & \\
\hline Contraception is & Disagree & 4092 (96.0\%) & 382 (8.5\%) & 0.5 & $0.4-0.6$ & 0.01 \\
\hline woman business & Don't know & 517 (97.5\%) & $3(2.5 \%)$ & 0.5 & $0.3-.9$ & 0.04 \\
\hline
\end{tabular}

FP: family planning. Data presented as Odd Ratio $(95 \% \mathrm{Cl})$. Statistically significant at $\mathrm{p}<0.05$.

\section{DISCUSSION}

This study examined the associations between socio-demographic determinants and male contraceptive use among couples in Indonesia based on the 2012 Indonesia Demographic and Health Survey. Male contraceptive use showed significant variation according to sociodemographic characteristics of Indonesia couples. Couples living in urban areas are more likely to use male contraceptive methods compared with couples living in rural areas. A similar finding was observed in studies conducted in Uttar Pradesh India that couples living in urban areas have positive gender-equitable attitudes in contraceptive intake ${ }^{29}$. Moreover, couples living in rural areas had more difficulties in getting adequate access to male contraceptives availability and services ${ }^{30-32}$.

Couples' whose husband approve family planning had greater probabilities to adopt male contraception. In patriarchy societies like Indonesia, where men have a dominant role over their wives' reproductive decisions, approval of family planning is a precondition for the successful practice of contraception ${ }^{33}$. A study conducted in
Bangladesh also showed that approval of husbands on family planning indicates that women will get full support from her husband for use and when confronted with side-effects of contraception ${ }^{16}$.

Moreover, male contraceptive use is significantly higher among couples whose husbands and wives read family planning from newspaper and magazines than those who have not received it at all. This is because both husbands and wives who read newspaper and magazine tend to have better educational attainment which in turn might affect gender sensitive decision making on the number of children desired ${ }^{22}$.

Beyond the socio-demographic variables, negative perception that contraception is woman business has associated with the unwillingness of couples to use male contraception. Other perception that a woman has the capability to get pregnant, thus, a woman should be the one to get contraception. Some studies indicate similar findings ${ }^{34,35}$.

This study is susceptible to several limitations. First, recall bias due to the history of retrospective contraceptive use among men. To attenuate this bias, we only included information from the 
current use of male contraceptive method. Another limitation of this nation-wide study was the incomplete coverage of the system. The IDHS is only designed to represent national and provincial levels, limiting the ability of data users to provide data beyond those levels. Lastly, the 2017 Indonesia Demographic and Health Survey (IDHS) had been conducted. Nevertheless, analyzing and cleaning the data need two years after the survey has been completed ${ }^{36}$. Thus, timeliness is another concern of the survey.

\section{CONCLUSION}

The study shows that for more than a decade, male methods (condom, male sterilization, periodic abstinence, and withdrawal) were less popular compared to female methods. The perception that contraception is a woman's business has been found as the highest predictor of male contraceptive use in Indonesia. Place of residence, husbands approve family planning, husbands and wives knew family planning from newspaper/ magazine, and the perception that contraception is woman's business were significantly associated with male's contraceptive use. Hence, gender-sensitive campaign on family planning, as well as gender-sensitive education curricula in schools, need to be done to increase the male contraceptive use in the future.

\section{ACKNOWLEDGEMENTS}

We would like to personally thank Prof. Meiwita P. Budiharsana and Dr. Wendy Hartanto for reviewing the document. We also gratefully acknowledge the ICF International Institutional Review Board (IRB), the Statistics Indonesia, the Indonesia Ministry of Health and the Indonesia National Population and Family Planning Board (BKKBN) for data collection and processing.

\section{REFERENCES}

1. United Nations. The Sustainable Development Goals Report. Geneva: United Nations, 2017.

2. Girard F. Taking ICPD beyond 2015: Negotiating sexual and reproductive rights in the next development agenda. Glob Public Health 2014; 9(6):607-19.

3. Kiani MFK. Motivation and involvement of men in family planning in Pakistan. Pak Dev Rev 2003; 42(3):197-217.

4. Pemerintah Republik Indonesia. Peraturan Republik Indonesia Nomor 5 Tahun 2010 tentang Rencana Pembangunan Jangka
Menengah Nasional Tahun 2010-2014. Jakarta: Kementerian PPN/BAPPENAS 2010.

5. Pemerintah Republik Indonesia. Peraturan Presiden Republik Indonesia Nomor 2 Tahun 2015 tentang Rencana Pembangunan Jangka Menengah Nasional 2015-2019. Jakarta: Kementerian PPN/BAPPENAS 2015.

6. Kassa M, Abajobir AA, Gedefaw M. Level of male involvement and associated factors in family planning services utilization among married men in Debremarkos town, Northwest Ethiopia. BMC Int Health Hum Rights 2014; 14(1):1-8.

7. Le Guen M, Ventola C, Bohet A, Moreau C, Bajos N. Men's contraceptive practices in France: Evidence of male involvement in family planning. Contraception 2015; 92(1):46-54.

8. Badan Kependudukan dan Keluarga Berencana Nasional (BKKBN). Rencana Stategis BKKBN 2010-2014. Jakarta: BKKBN 2011.

9. Budiharsana, M. Contraceptive services available to unmarried sexually active adolescents. Makara J Heal Res 2017; 21(2):68-74.

10. Badan Pusat Statistik (BPS), Badan Kependudukan dan Keluarga Berencana Nasional (BKKBN), Kementerian Kesehatan, Measure DHS, ICF International. Survei Demografi dan Kesehatan Indonesia 2012. Jakarta: BKKBN 2013.

11. Badan Pusat Statistik (BPS), Badan Koordinasi Keluarga Berencana Nasional (BKKBN), Kementerian Kesehatan, Macro International. Survei Demografi dan Kesehatan Indonesia 2007. Jakarta: BKKBN 2008.

12. Oyediran KA, Isiugo-Abanihe UC. Husbandwife communication and couple's fertility desires among the Yoruba of Nigeria. African Popul Stud 2002; 17(2):61-80.

13. Lasee A, Becker S. Husband-wife communication about family planning and contraceptive use in Kenya. Int Fam Plan Perspect 1997; 23(1):15-21.

14. Prata N, Bell S, Fraser A, Carvalho A, Neves I. Nieto-Andrade, B. Partner support 
for family planning and modern contraceptive use in Luanda, Angola. African J Reprod Heal 2017; 21(212):3548.

15. Memmi S, du Loû AD, Grieve M. 'Gender relations and contraceptive practices of Palestinian couples'. Population 2015; 70(2):273-93.

16. Islam MA, Padmadas SS, Smith PWF. Men's approval of family planning in Bangladesh. J Biosoc Sci 2004; 38(2):247-59.

17. Adongo PB, Tapsoba P, Phillips JF, Tabong PTN, Stone A, Kuffour E, Esantsi SF, Aweongo P. "If you do vasectomy and come back here weak, i will divorce you": A qualitative study of community perceptions about vasectomy in Southern Ghana. BMC Int Health Hum Rights 2014; 14(1):1-8.

18. Adanikin Al, MCGrath N, Padmadas SS. Impact of men's perception on family planning demand and uptake in Nigeria. Sex Reprod Healthc 2017; 14(2017):55-63.

19. Albarracín D, Kumkale GT, Johnson BT. Influences of social power and normative support on condom use decisions: A research synthesis. AIDS Care-Psychol Socio-Medical Asp AIDS/HIV 2004; 16(6):700-23.

20. Adelekan A, Omoregie P, Edoni E, Adelekan A, Omoregie P, Edoni E. Male involvement in family planning: challenges and way forward. Int J Popul Res 2014; 2014:1-9.

21. Mardiana M, Abdullah KL, Oo SS, Akhtar K, Sulaini AJ, Suriawati G, Haque M, Choon LM. The prevalence of family planning practice and associated factors among women in Serdang, Selangor. Malaysian $J$ Public Heal Med 2015; 15(3):147-56.

22. Kabir M, Islam MA. The impact of mass media family planning programmes on current use of contraception planning programmes on current use in Urban Bangladesh. J Biosoc Sci 2000; 32:411-9.

23. Ardiansyah B. Effect of mass media on family planning choices in Indonesia. MPA/MPP Capstone Projects 2016. http://martin.uky.edu/sites/martin.uky.e du/files/Capstone_Projects/Capstones_201 6/Ardiansyah.pdf (accesed 12 January 2019).
24. Rutstein SO. Rojas G. Guide to DHS Statistics: Demographic and Health Surveys Methodology. Maryland: Measure DHS 2006.

25. Ross J, Hardee K. Use of male methods of contraception worldwide. J Biosoc Sci 2017; 49(5):648-63.

26. Griffith A. SPSS For Dummies (2nd Edition). Indiana: Wiley Publishing 2010:1-387.

27. Khorshed $\mathrm{AM}$, Bhaskara RM, Cheng F-C. Sample size determination in logistic regression. Sankhya Indian J Stat 2010; $72-$ B(1):58-75.

28. Hosmer DW, Lemeshow S. Applied Logistic Regression. Wiley-Interscience Publication. 2000:1-373.

29. Mishra A, Nanda P, Speizer IS, Calhoun LM, Zimmerman A, Bhardwaj R. Men' s attitudes on gender equality and their contraceptive use in Uttar Pradesh India. Reprod Health 2014; 11(41):1-13.

30. Mesfin G. The role of men in fertility and family planning program in Tigray Region. Ethiop J Heal Dev 2002; 16(3):247-55.

31. Dodoo FNA, Tempenis M. Gender, power and reproduction: Rural-urban differences in the relationship between fertility goals and contraceptive use in Kenya. Rural Sociol 2002; 67(1):46-70.

32. Irani L, Speizer IS, Fotso J-C. Relationship Characteristics and Contraceptive Use Among Couples in Urban Kenya. Int Perspect Sex Reprod Health 2014; 40(01):11-20.

33. Joesoef MR, Baughman AL, Utomo B. Approval of contraceptive use in Indonesia : Program Implications. Stud Fam Plann 2015; 19(3):162-8.

34. Madhukumar S, Pavithra M. A study about perceptions, attitude, and knowledge among men toward vasectomy in Bangalore rural population. Int J Med Sci Public Heal 2015; 4(8):1066-70.

35. Nair GR, Wadke R, Relwani N, Mahadik V, Anjenaya $S$. Knowledge and attitude of married men towards vasectomy in an urban slum of Navi Mumbai. Int $J$ Community Med Public Heal 2017; 4(12):4563-8. 
36. Development Initiatives. Household Surveys. 2017. http://devinit.org/post/ key-facts-on-household-surveys/ (accesed 1 March 2019). 